\title{
The Association Between Procalcitonin, Lactate Level, and Clinical Prognosis in Patients with Crimean-Congo Hemorrhagic Fever
}

\author{
Kırım-Kongo Kanamalı Ateşi Hastalarında Prokalsitonin ve Laktat Düzeyinin Klinik Seyirle İlişkisi
}

\author{
Ferhan KERGET ${ }^{\mathbf{1}}$ \\ (D) 0000-0002-5160-4854 \\ Buğra KERGET ${ }^{2}$ \\ (D) 0000-0002-6048-1462 \\ Sibel İBA YILMAZ ${ }^{1}$ \\ (D) 0000-0002-4123-0828
}

\begin{abstract}
${ }^{1}$ Depertmant of Infectious Diseases and Clinical Microbiology, Health Sciences University Erzurum Regional Education and Research Hospital, Erzurum, Turkey
\end{abstract}

${ }^{2}$ Department of Pulmonary Diseases, Ataturk University School of Medicine, Erzurum, Turkey

\section{Corresponding Author Sorumlu Yazar \\ Buğra KERGET \\ bjkerget1903@gmail.com}

Received / Geliş Tarihi : 20.10.2021 Accepted / Kabul Tarihi : 06.12.2021 Available Online /

Çevrimiçi Yayın Tarihi : 15.12.2021

\begin{abstract}
Aim: Crimean-Congo hemorrhagic fever (CCHF) is a zoonotic infection characterized by fever and hemorrhage that is endemic to northeastern Turkey. This study aimed to examine the association between procalcitonin and venous blood gas parameters and clinical course and prognosis in patients with CCHF.

Material and Methods: A total of $96 \mathrm{CCHF}$ patients who were followed up in the infectious diseases department between March 2020 and September 2020 were included in the study. The patients' routine laboratory tests, serum procalcitonin, and results of venous blood gas analysis were analyzed retrospectively.

Results: There were statistically significant differences in serum platelet, aspartate transaminase, alanine transaminase, creatinine kinase, lactate dehydrogenase, potassium, Creactive protein, sedimentation, D-dimer, activated partial thromboplastin time, ferritin, procalcitonin and lactate levels, and platelet/lymphocyte ratio among the patients with mild, moderate and severe disease $(\mathrm{p}=0.017$ for potassium, $\mathrm{p}=0.004$ for $\mathrm{D}$-dimer, and $\mathrm{p}<0.001$ for rest of others). In receiver operating characteristic curve analysis of serum lactate for the differentiation of patients with severe disease and those with mild/moderate disease, the area under curve was 0.802 and a cut-off value of $1.9 \mathrm{mmol} / \mathrm{L}$ had $77.8 \%$ sensitivity and $76.9 \%$ specificity. For serum procalcitonin, the area under curve was 0.892 and a cut-off value of 0.61 $\mathrm{ng} / \mathrm{mL}$ had $83.3 \%$ sensitivity and $89.7 \%$ specificity.

Conclusion: Serum procalcitonin and lactate level may be useful and easily obtained parameters to guide the evaluation of clinical severity and follow-up in patients with CCHF. Keywords: Lactate; Crimean-Congo hemorrhagic fever; procalcitonin.
\end{abstract}

\section{ÖZ}

Amaç: Kırım-Kongo kanamalı ateşi (KKKA) ateş ve kanama ile seyreden Türkiye'nin Kuzeydoğusunda endemik olarak gözlenen zoonotik bir enfeksiyondur. Bu çalışmada KKKA hastalarında prokalsitonin ve venöz kan gazı parametrelerinin klinik seyir ve prognoz ile ilişkisinin incelenmesi amaçlanmıştır.

Gereç ve Yöntemler: Mart 2020 ve Eylül 2020 tarihleri arasında enfeksiyon hastalıkları kliniğinde takip edilen toplam 96 KKKA hastası çalışmaya dahil edildi. Hastaların rutin laboratuvar tetkikleri, serum prokalsitonin ve venöz kan gazı analizi bulguları geriye dönük olarak analiz edildi.

Bulgular: Hafif, orta ve ağır hastalığı olan hastalar arasındaki serum trombosit, aspartat transaminaz, alanin transaminaz, kreatinin kinaz, laktat dehidrojenaz, potasyum, C-reaktif protein, sedimantasyon, D-dimer, aktive parsiyel tromboplastin zamanı, ferritin, prokalsitonin ve laktat seviyeleri ve trombosit/lenfosit açısından istatistiksel olarak anlamlı farklılıklar vardı (potasyum için $p=0,017$; D-Dimer için $p=0,004$ ve geri kalan diğerleri için $p<0,001$ ). Ağır hastalığı olan ve hafif/orta hastalığı olan hastaların ayrımı için serum laktat düzeyinin alıcı işlem karakteristiği eğrisi analizinde, eğri altında kalan alan 0,802 idi ve kesim değeri 1.9 $\mathrm{mmol} / \mathrm{L}$ alındığında $\% 77,8$ duyarlılığa ve $\% 76,9$ özgüllüğe sahipti. Serum prokalsitonin için eğri altında kalan alan 0,892 idi ve $0.61 \mathrm{ng} / \mathrm{mL}$ 'lik bir kesim değeri alındığında \% $\% 3,3$ duyarlılık ve \%89,7 özgüllüğe sahipti.

Sonuç: Serum prokalsitonin ve laktat düzeyi KKKA hastalarında klinik şiddetin değerlendirilmesinde ve takipte yol gösterici olması açısından yararlı ve kolay elde edilen parametreler olabilirler.

Anahtar kelimeler: Laktat; Kırım-Kongo kanamalı ateşi; prokalsitonin. 


\section{INTRODUCTION}

Crimean-Congo hemorrhagic fever (CCHF) is an endemic disease in the Northern Anatolia Region of Turkey that is characterized by fever and hemorrhage and can have a severe and potentially life-threatening course (1). The CCHF virus is generally transmitted to humans through tick bites or contact with infected ticks or the bodily fluids of infected animals. The main targets of CCHF are mononuclear phagocytes, endothelial cells, and hepatocytes (2). Signs and symptoms occur as a result of the effect of the virus on target organs. Sudden-onset fever, headache, malaise, anorexia, widespread body pain, and nausea are the most common symptoms (3).

The pathogenesis of CCHF is not fully understood, though macrophage activation and hemophagocytosis are known to be the basis of the pathological process. After entering the body, the virus proliferates in local lymph nodes and tissues, then spreads via the lymph and monocytes to other parts of the body, especially the spleen, liver, lymph ganglia, lungs, adrenal glands, and endothelium (4). Secondary infection of parenchymal cells occurs by macrophage migration. Macrophage and endothelial cell activation induces inflammatory and vasoactive processes, resulting in systemic inflammatory response syndrome (SIRS) (5). Coagulation system activation and extensive fibrin accumulation in the vascular beds lead to disseminated intravascular coagulation (DIC) and multiple organ failure (MOF) (2).

Blood gas analysis is important for evaluating prognosis in SIRS and MOF. Studies have shown that low $\mathrm{pH}$, high lactate, and low carboxyhemoglobin levels in venous blood gas analysis are important markers of clinical course and prognosis (6). In particular, lactate level is a serum marker frequently used in clinical practice. High serum lactate is an indicator of tissue hypoperfusion. Lactate is produced by many tissues of the human body and at high levels in muscle tissue. Under normal circumstances, lactate is rapidly eliminated by the liver and partly by the kidneys (7).

Procalcitonin level is believed to increase mostly in bacterial infections and sepsis as part of the systemic inflammatory response against infection. It is generally not expected to increase in response to viral infections. However, it has been suggested that a major increase in cytokine levels may lead to procalcitonin elevation (8).

The aim of this study was to evaluate the relationship between procalcitonin level and venous blood gas parameters and the clinical course and prognosis of CCHF.

\section{MATERIAL AND METHODS}

\section{Study Design}

This retrospective study included patients who were under follow-up for CCHF between March 2020 and September 2020. The study was designed and conducted in accordance with the ethical guidelines set forth in the Declaration of Helsinki. The study protocol was approved by the local ethics committee $(02.11 .2020,20-189)$ and written informed consent was obtained from all patients included in the study.

\section{Sample Size and Patients}

We calculated minimum sample size as 84 patients with an effect size of 0.4 , type 1 error of 0.05 , and a power of 0.90 for testing three groups using GPower 3.1 software.
A total of 96 patients (58 male, 38 female) aged 18 years and older who were followed up for CCHF in the Erzurum Regional Training and Research Hospital Department of Infectious Diseases were included in the study. Patients who developed bacterial superinfection confirmed by blood, sputum, and urine cultures during CCHF follow-up and patients who were pregnant, had known malignancies, had liver or kidney failure, used anti-inflammatory drugs in the last month, or were followed up for acute coronary syndrome in the last 2 months were excluded.

\section{Study Groups}

The patients were classified as having mild, moderate, or severe disease according to the criteria defined by Swanepoel et al. (9) and the modified criteria recommended by Ergönül et al. (10), as well as clinical indicators of poor prognosis. Accordingly, there were 37 patients in the mild group, 40 patients in the moderate group, and 19 patients in the severe group. Blood, urine, and sputum cultures were performed for all patients whose procalcitonin level exceeded the upper laboratory limit.

\section{CCHF Diagnosis}

Two blood samples of at least $2 \mathrm{~mL}$ each were collected from every patient with suspected CCHF upon hospital admission. After 30 minutes of coagulation, the samples were centrifuged at $2000 \mathrm{rpm}$ for $5 \mathrm{~min}$ and the serum was transferred to separate tubes. One serum sample from each patient was transported under appropriate conditions to the Erzurum Regional Public Health Laboratory, regional reference center, for serologic and virologic tests. CCHF was diagnosed based on specific anti-IgM antibody detected by immunofluorescence assay (IFA) and/or polymerase chain reaction (PCR) positivity.

\section{Measurement of Biochemical Markers}

All the serum samples were obtained within the first 2 days of the onset of their symptoms. Further, the patients' biochemical and hematological parameters were tested on admission, in the laboratory. Procalcitonin levels were tested with commercial ELISA kits (Elecsys BRAHMS PCT, Roche, Mannheim, Germany), according to the manufacturer's recommendations.

\section{Statistical Analysis}

Data analysis was performed with IBM SPSS Statistics for Windows version 22.0 (IBM Corp., Armonk, NY) and Medcalc version 16 (MedCalc Software bvba, Ostend, Belgium). Shapiro-Wilk and Kolmogorov-Smirnov tests were used to evaluate the normality assumption. The descriptive statistics were presented as frequency with percentage for categorical variables, and as median with interquartile range (IQR) for numeric data. The laboratory findings were compared among the study groups using Kruskal-Wallis test. Post hoc comparisons were done using Dunn's post hoc test with Bonferroni correction. Spearman correlation analysis was used to evaluate the relationships between serum procalcitonin, lactate, aspartate transaminase (AST) and alanine transaminase (ALT) levels. Receiver operating characteristic (ROC) curve analysis was used to estimate the severe disease using serum procalcitonin and lactate levels. Youden index was used to find the best cut-off values. The area under curve (AUC), sensitivity and specificity with 95\% confidence interval (CI) were calculated. A p-value less than 0.05 was considered statistically significant. 


\section{RESULTS}

Of the 96 CCHF patients in this study, 58 (60.4\%) were male and $38(39.6 \%)$ were female. The median age of the study group was 50 years with a range of $18-79$ years. The clinical symptoms are shown in Table 1 . The most common symptoms were malaise, fever, and myalgia/arthralgia, respectively.

The patients' laboratory findings are shown in Table 2. There were statistically significant differences in serum platelet, AST, ALT, creatinine kinase (CK), lactate dehydrogenase (LDH), potassium, C-reactive protein (CRP), sedimentation, D-dimer, activated partial thromboplastin time (aPTT), ferritin, procalcitonin and lactate levels, and platelet/lymphocyte ratio (PLR) among the patients with mild, moderate and severe disease $(\mathrm{p}=0.017$ for potassium, $\mathrm{p}=0.004$ for $\mathrm{D}$-dimer, and $\mathrm{p}<0.001$ for rest of others).

PLR was significantly lower in patients with severe and moderate disease compared to those with mild disease (both $\mathrm{p}<0.001$ ). Serum CRP level was statistically significantly higher in patients with severe disease compared to those with moderate disease and with mild disease $(\mathrm{p}=0.049$ and $\mathrm{p}<0.001$, respectively), and also there was statistically significant difference in serum CRP level among the patients with moderate disease and with mild disease $(p=0.024)$. Serum D-dimer level was statistically significantly higher in patients with severe disease compared to those with mild disease $(p=0.002)$. Ferritin level was significantly higher in patients with severe disease compared to those with moderate disease

Table 1. Clinical symptoms of the patients

\begin{tabular}{lc}
\hline Symptoms & $\mathbf{n}(\boldsymbol{\%})$ \\
\hline Malaise & $96(100)$ \\
Fever & $92(95.8)$ \\
Myalgia and/or arthralgia & $80(83.3)$ \\
Rash & $54(56.3)$ \\
Nausea & $51(53.1)$ \\
Headache & $38(39.6)$ \\
Vomiting & $33(34.4)$ \\
Abdominal pain & $20(20.8)$ \\
Hemorrhage & $20(20.8)$ \\
Diarrhea & $17(17.7)$ \\
Chest pain & $13(13.5)$ \\
\hline
\end{tabular}

Table 2. Comparison of laboratory parameters according to the disease severity

\begin{tabular}{|c|c|c|c|c|}
\hline Parameters & Mild (n=37) & Moderate $(n=40)$ & Severe $(n=19)$ & $\mathbf{p}$ \\
\hline Hemoglobin $(\mathrm{g} / \mathrm{L})$ & $13.6(12.6-14.8)$ [7.7-16.9] & $14.3(12.7-15.1)[8.1-16.7]$ & $13.7(12.7-14.9)[6.2-17.6]$ & 0.691 \\
\hline WBC $(1000$ cells $/ \mu \mathrm{L})$ & $2.2(1.7-2.9)$ [1.15-3.97] & $1.9(1.5-2.9)[0.82-5.11]$ & $2.6(1.8-3.4)[0.64-3.89]$ & 0.232 \\
\hline Platelets (1000 cells/ $\mu \mathrm{L})$ & $94(55-122)$ [19-159] & $42.5(32-69.3)[12-140]$ & $28(19-45)[8-114]$ & $<0.001$ \\
\hline Neutrophils (cells $/ \mu \mathrm{L}$ ) & $910(645-1535)$ [250-2390] & 755 (590-977.5) [250-3780] & $1030(710-1570)$ [300-3110] & 0.152 \\
\hline Leukocytes (cells $/ \mu \mathrm{L})$ & $930(700-1282)[440-2130]$ & $875(630-1392.5)$ [170-2340] & $880(520-1770)$ [280-2110] & 0.964 \\
\hline NLR & $1.01(0.59-1.66)[0.17-5.43]$ & $0.84(0.56-1.25)[0.29-5.47]$ & $1.07(0.60-1.68)[0.36-11.11]$ & 0.524 \\
\hline PLR & $92.7(51.4-150.7)$ [26.9-286.4] & $59.6(28.7-79.2)[13.7-325.0]$ & $32.9(21.7-54.0)[4.5-172.4]$ & $<0.001$ \\
\hline Monocytes (cells $/ \mu \mathrm{L})$ & $220(155-280)$ [80-710] & 205 (150-305) [40-860] & $260(110-460)[10-700]$ & 0.581 \\
\hline Eosinophils (cells $/ \mu \mathrm{L})$ & $10(0-30)[0-200]$ & $10(0-17.5)[0-120]$ & $1(0-20)[0-60]$ & 0.751 \\
\hline AST (U/L) & $81(44.5-142.5)$ [28-650] & $298.5(230-405)$ [166-687] & $844(605-1060)$ [271-4223] & $<0.001$ \\
\hline $\operatorname{ALT}(\mathrm{U} / \mathrm{L})$ & $68(42.5-106)[11-316]$ & $220(139-300)$ [12-546] & 415 (229-481) [125-1617] & $<0.001$ \\
\hline $\mathrm{CK}(\mathrm{U} / \mathrm{L})$ & $200(107.5-545)$ [33-1298] & 401.5 (218.8-918.3) [123-3650] & 1135 (461-2766) [133-7800] & $<0.001$ \\
\hline LDH (U/L) & $353(285.5-457.5)$ [214-863] & $570(460.8-750)$ [24-1161] & $1101(750-1840)$ [531-4380] & $<0.001$ \\
\hline Creatinine (mg/dL) & $0.80(0.72-0.99)[0.51-1.46]$ & $0.76(0.63-0.92)[0.31-1.47]$ & $0.85(0.71-1.08)[0.53-7.90]$ & 0.184 \\
\hline Sodium $(\mathrm{mmol} / \mathrm{L})$ & $133(132-135)$ [125-140] & $133(131-134)$ [127-136] & $131(129-133)$ [126-155] & 0.077 \\
\hline Potassium (mmol/L) & $3.8(3.4-4.1)[2.6-4.5]$ & $3.6(3.3-3.7)[0.9-4.2]$ & $3.3(3.1-3.7)[2.4-4.2]$ & 0.017 \\
\hline CRP (mg/L) & $3(2.4-10.5)[0.2-47.6]$ & $11(3.0-23.8)[0.6-80.0]$ & $41(10.4-85.0)[1.0-183.0]$ & $<0.001$ \\
\hline Sedimentation (s) & $6(2-11)[2-92]$ & $11(5-22)[1-35]$ & $33(14-50)$ [2-97] & $<0.001$ \\
\hline Fibrinogen (mg/dl) & $242(206-294.5)$ [109-445] & $208(166.8-275.8)$ [148-574] & $202(167-293)[117-361]$ & 0.165 \\
\hline D-dimer (ng/mL) & $1.7(0.9-4.4)[0.1-8.8]$ & $2.7(1.2-5.3)[0.2-80.0]$ & $7.5(1.4-44.5)[0.6-80.0]$ & 0.004 \\
\hline PT (s) & $14.5(12.8-16.4)$ [11.4-23.9] & $13.7(12.6-15.0)[11.7-20.0]$ & $13.6(12.3-17.4)[11.5-23.6]$ & 0.801 \\
\hline aPTT (s) & $32.7(30.4-35.6)[25.4-41.8]$ & $35.9(32.6-42.4)[27.0-82.6]$ & $48.9(37.7-57.6)$ [29.6-69.9] & $<0.001$ \\
\hline INR & $1.08(0.99-1.26)$ [0.37-1.89] & $1.19(1.04-1.41)[0.94-1.82]$ & $1.23(1.01-1.76)$ [0.85-4.30] & 0.117 \\
\hline Ferritin (ng/mL) & $76(61.5-101)[9.6-634]$ & $250(150-705)[44.5-8746]$ & $1033(408-2000)$ [41-6500] & $<0.001$ \\
\hline Procalcitonin $(\mathrm{ng} / \mathrm{mL})$ & $0.03(0.03-0.08)[0.01-1.42]$ & $0.14(0.05-0.53)[0.01-2.20]$ & $2.00(1.30-5.20)[0.05-36.59]$ & $<0.001$ \\
\hline $\mathrm{pH}$ & $7.40(7.38-7.42)$ [7.35-7.49] & $7.42(7.38-7.45)[7.27-7.50]$ & $7.40(7.32-7.44)$ [7.25-7.49] & 0.347 \\
\hline Lactate $(\mathrm{mmol} / \mathrm{L})$ & $1.5(1.2-1.8)[0.8-2.4]$ & $1.7(1.3-2.1)[1.0-3.3]$ & $2.2(2.0-3.2)[1.4-5.5]$ & $<0.001$ \\
\hline $\mathrm{COHb}(\%)$ & $0.6(0.5-0.7)[0.2-2.2]$ & $0.8(0.6-0.9)$ [0.3-1.7] & $0.6(0.5-0.9)[0.2-2.0]$ & 0.051 \\
\hline
\end{tabular}

Descriptive statistics were given as median (interquartile range, Q1-Q3) [min-max], WBC: white blood cells, NLR: neutrophil/lymphocyte ratio, PLR: platelet/lymphocyte ratio, AST: aspartate transaminase, ALT: alanine transaminase, CK: creatinine kinase, LDH: lactate dehydrogenase, CRP: C-reactive protein, PT: prothrombin time, aPTT: activated partial thromboplastin time, INR: international normalized ratio, $\mathrm{COHb}$ : carboxyhemoglobin 
and with mild disease (both $\mathrm{p}<0.001$ ). Serum procalcitonin level was statistically significantly higher in patients with severe disease compared to those with moderate disease and with mild disease $(\mathrm{p}=0.001$ and $\mathrm{p}<0.001$, respectively), and also there was a statistically significant difference in serum procalcitonin level among the patients with moderate disease and with mild disease $(p=0.005)$. Serum lactate level was statistically significantly higher in patients with severe disease compared to those with moderate disease and with mild disease $(\mathrm{p}=0.004$ and $\mathrm{p}<0.001$, respectively).

For serum procalcitonin and lactate levels in differentiating severe and moderate/mild disease, the AUC values were 0.892 and 0.802 , and the best cut-off points were $>0.61$ and $>1.9$, respectively. According to these cut-off values, the sensitivity and specificity of procalcitonin were $83.3 \%$ and $89.7 \%$, and the sensitivity and specificity of lactate were $77.8 \%$ and $76.9 \%$, respectively (Table 3 and Figure 1).

There were statistically significantly medium positive correlations between serum procalcitonin level and serum AST $\left(\mathrm{r}_{\mathrm{s}}=0.584, \mathrm{p}<0.001\right)$, ALT $\left(\mathrm{r}_{\mathrm{s}}=0.497, \mathrm{p}<0.001\right)$ and lactate $\left(r_{s}=0.441, p<0.001\right)$ levels. Serum lactate level was also positively correlated with serum AST $\left(r_{s}=0.459, p<0.001\right)$ and ALT $\left(r_{s}=0.446, p<0.001\right)$ levels (Table 4).

\section{DISCUSSION}

In this study, we found that procalcitonin and lactate levels were higher in patients with severe CCHF when compared to patients with mild and moderate CCHF. In the differentiation of severely ill patients from mild/moderately ill patients, a lactate cut-off value of 1.9 $\mathrm{mmol} / \mathrm{L}$ had $77.8 \%$ sensitivity and $76.9 \%$ specificity, whereas a procalcitonin cut-off value of $0.61 \mathrm{ng} / \mathrm{mL}$ had $83.3 \%$ sensitivity and $89.7 \%$ specificity. Both procalcitonin and lactate levels were positively correlated with AST and ALT, which are frequently used parameters in CCHF follow-up.

Table 3. Comparison of AUC, sensitivity and specificity of serum procalcitonin and lactate levels in differentiating severe and moderate/mild disease

\begin{tabular}{lcc}
\hline & Procalcitonin & Lactate \\
\hline AUC (95\% CI) & $0.892(0.813-0.946)$ & $0.802(0.708-0.876)$ \\
Youden index & 0.731 & 0.547 \\
Associated cut-off & $>0.61$ & $>1.9$ \\
Sensitivity (95\% CI) & $83.3(58.6-96.4)$ & $77.8(52.4-93.6)$ \\
Specificity (95\% CI) & $89.7(80.8-95.5)$ & $76.9(66.0-85.7)$ \\
\hline AUC: area under curve, CI: confidence interval &
\end{tabular}

Table 4. Correlations between serum procalcitonin, AST, ALT and lactate levels

\begin{tabular}{lcccc}
\hline & \multicolumn{2}{c}{ Procalcitonin } & \multicolumn{2}{c}{ Lactate } \\
\cline { 2 - 5 } & $\mathbf{r}_{\mathbf{s}}$ & $\mathbf{p}$ & $\mathbf{r}_{\mathbf{s}}$ & $\mathbf{p}$ \\
\hline Procalcitonin & & & 0.441 & $<\mathbf{0 . 0 0 1}$ \\
Lactate & 0.441 & $<\mathbf{0 . 0 0 1}$ & & \\
AST & 0.584 & $<\mathbf{0 . 0 0 1}$ & 0.459 & $<\mathbf{0 . 0 0 1}$ \\
ALT & 0.497 & $<\mathbf{0 . 0 0 1}$ & 0.446 & $<\mathbf{0 . 0 0 1}$ \\
\hline AST: aspartate transaminase, ALT: alanine transaminase, rs: $_{\text {s: }}$ Spearman's rho
\end{tabular}

As in all viral hemorrhagic fevers, the basis of CCHF pathogenesis is viral infection of various cell types, primarily endothelial cells, mononuclear cells, and hepatocytes, followed by proliferation and systematic spread $(11,12)$. Increased endothelial permeability and consequent endothelial damage is the main pathogenetic process leading to death. This endothelial damage has been attributed to two main mechanisms. The first is a direct viral effect on the endothelial cells, and the second is damage caused indirectly by the cytokines secreted from infected tissues $(9,13,14)$.

The most important of these cytokines are tumor necrosis factor alpha, interleukin (IL)-1, and IL-6, which are synthesized by type 1 helper $\mathrm{T}$ cells and are involved in monocyte activation. The activation of monocytes by cytokines impairs platelet activation and degranulation and leads to an abnormal coagulation cascade in CCHF (15). Monocyte activation is considered one of the main causes of hemophagocytic lymphohistiocytosis, which leads to cytopenia and liver dysfunction in CCHF. Serum AST, ALT, LDH, and CK are liver function indicators that are frequently used parameters in clinical follow-up and have been associated with poor prognosis (16-18).

Serum lactate level is another parameter frequently used in the clinical practice, and although it may increase secondary to tissue hypoperfusion, elevation may also occur due to causes unrelated to hypoperfusion (19). Lactate, which can be synthesized in many of the body's tissues, is eliminated primarily by the liver and to a lesser extent by the kidneys. A substantial proportion of studies evaluating the relationship between lactate level and clinical course and prognosis have observed that hypoperfusion increases lactate level due to sepsis and septic shock $(20,21)$. Our literature search yielded no studies in which lactate level was associated with the clinical course of CCHF. In the present study, serum lactate level was found to increase in correlation with clinical severity in CCHF patients. This may be attributed

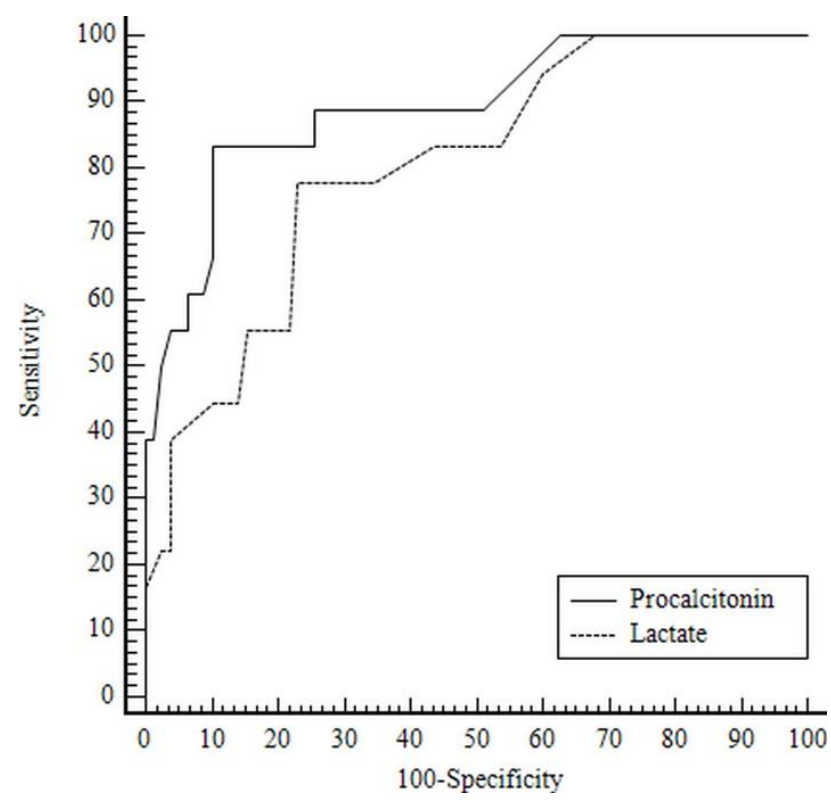

Figure 1. Receiver operating characteristic curve of serum lactate and procalcitonin levels in differentiating the severe and mild/moderate disease 
to the inadequate elimination of lactate by the liver in CCHF, as liver dysfunction due to hemophagocytic lymphohistiocytosis plays an important role in the clinical course of this condition. Moreover, the increased cytokine levels seen in CCHF due to the indirect effect of the virus might have led to muscle dysfunction and higher levels of $\mathrm{CK}$ as well as lactate. This is corroborated by the fact that muscle and joint pain are among the most common presenting symptoms.

High serum procalcitonin level is often observed in bacterial infections rather than viral infections. However, it has been found that increased cytokine levels also increase amount of procalcitonin synthesized by thyroid $\mathrm{C}$ cells in viral infections, independent of bacterial superinfections $(8,22,23)$. Procalcitonin level was reported to be higher in patients with fatal CCHF and correlated with CRP level, which is frequently used in routine practice (24). None of the patients in this study died after clinical follow-up, and in line with previous studies, we also found that procalcitonin levels were higher in severely ill patients. This level also correlated with liver function markers and serum lactate level. The lack of growth in blood, urine, and sputum cultures performed after the increase in procalcitonin levels suggest that this was due to high cytokine level.

The main limitation of our study was the inability to detect an association between lactate and procalcitonin levels and mortality. This was primarily due to the fact that during the study period, our hospital was designated as a COVID-19 pandemic hospital during the pandemic, and as a result there was a sharp decline in the number of patients we followed due to CCHF in our hospital.

\section{CONCLUSION}

In conclusion, serum procalcitonin and lactate levels may be important parameters for the early evaluation of clinical course and prognosis in patients with CCHF. Large scale studies evaluating the association between these two parameters and clinical course and mortality may provide more guidance in the course of the clinical follow-up.

Ethics Committee Approval: The study was approved by the Ethics Committee of Erzurum Regional Education and Research Hospital (02.11.2020, 20-189).

Conflict of Interest: None declared by the authors.

Financial Disclosure: None declared by the authors.

Acknowledgements: None declared by the authors.

Author Contributions: Idea/Concept: FK, SIY; Design: BK; Data Collection/Processing: FK, SIY; Analysis/Interpretation: BK; Literature Review: FK; Drafting/Writing: FK, BK; Critical Review: BK.

\section{REFERENCES}

1. Karti SS, Odabasi Z, Korten V, Yilmaz M, Sonmez M, Caylan R, et al. Crimean-Congo hemorrhagic fever in Turkey. Emerg Infect Dis. 2004;10(8):1379-84.

2. Leblebicioglu H, Ozaras R, Fletcher TE, Beeching NJ; ESCMID Study Group for Infections in Travellers and
Migrants (ESGITM). Crimean-Congo haemorrhagic fever in travellers: A systematic review. Travel Med Infect Dis. 2016;14(2):73-80.

3. Nasirian H. Crimean-Congo hemorrhagic fever (CCHF) seroprevalence: A systematic review and meta-analysis. Acta Trop. 2019;196:102-20.

4. Akıncı E, Bodur H, Leblebicioglu H. Pathogenesis of Crimean-Congo hemorrhagic fever. Vector Borne Zoonotic Dis. 2013;13(7):429-37.

5. Demirtas E, Bakir M, Buyuktuna SA, Oksuz C, Oz M, Cebecioglu K, et al. Comparison of the predictive performance of qSOFA, APACHE II and SGS for evaluation of the disease prognosis of CCHF patients at the emergency department. Jpn J Infect Dis. 2020:73(5):323-9.

6. Mazza BF, Machado FR, Mazza DD, Hassmann V. Evaluation of blood transfusion effects on mixed venous oxygen saturation and lactate levels in patients with SIRS/sepsis. Clinics (Sao Paulo). 2005;60(4):311-6.

7. Goyal M, Pines JM, Drumheller BC, Gaieski DF. Point-of-care testing at triage decreases time to lactate level in septic patients. J Emerg Med. 2010;38(5):57881.

8. Foushee JA, Hope NH, Grace EE. Applying biomarkers to clinical practice: a guide for utilizing procalcitonin assays. J Antimicrob Chemother. 2012;67(11):2560-9.

9. Swanepoel R, Gill DE, Shepherd AJ, Leman PA, Mynhardt JH, Harvey S. The clinical pathology of Crimean-Congo hemorrhagic fever. Rev Infect Dis. 1989;11(Suppl 4):S794-800.

10. Ergönül Ö, Şeref C, Eren Ş, Çelikbaş A, Baykam N, Dokuzoğuz B, et al. Cytokine response in CrimeanCongo hemorrhagic fever virus infection. J Med Virol. 2017;89(10):1707-13.

11. Kilinc C, Gückan R, Capraz M, Varol K, Zengin E, Mengeloglu Z, et al. Examination of the specific clinical symptoms and laboratory findings of CrimeanCongo hemorrhagic fever. J Vector Borne Dis. 2016;53(2):162-7.

12. Qaderi S, Mardani M, Shah A, Shah J, Bazgir N, Sayad $\mathrm{J}$, et al. Crimean-Congo hemorrhagic fever (CCHF) in Afghanistan: A retrospective single center study. Int J Infect Dis. 2021;103:323-8.

13. Burt FJ, Swanepoel R, Shieh WJ, Smith JF, Leman PA, Greer PW, et al. Immunohistochemical and in situ localization of Crimean-Congo hemorrhagic fever (CCHF) virus in human tissues and implications for CCHF pathogenesis. Arch Pathol Lab Med. 1997;121(8):839-46.

14. Kerget F, Özkurt Z, Öztürk N, Yilmaz S. The relationship with clinical course and prognosis of serum endothelin-1, angiopoietin-2, and tie-2 levels in Crimean-Congo hemorrhagic fever. Turk J Med Sci. 2019;49(4):1192-7.

15. Shahhosseini N, Wong G, Babuadze G, Camp JV, Ergonul O, Kobinger GP, et al. Crimean-Congo hemorrhagic fever virus in Asia, Africa and Europe. Microorganisms. 2021;9(9):1907.

16. Ergonul O, Tuncbilek S, Baykam N, Celikbas A, Dokuzoguz B. Evaluation of serum levels of interleukin (IL)-6, IL-10, and tumor necrosis factor- 
alpha in patients with Crimean-Congo hemorrhagic fever. J Infect Dis. 2006;193(7):941-4.

17. Ergönül Ö. Crimean-Congo haemorrhagic fever. Lancet Infect Dis. 2006;6(4):203-14.

18. Kerget F, Demirdöğen ŞO, Kerget B. Case report: A rare case of Crimean-Congo hemorrhagic fever associated with epididymo-orchitis. Am J Trop Med Hyg. 2021;104(3):1055-7.

19. Luft D, Deichsel G, Schmulling RM, Stein W, Eggstein M. Definition of clinically relevant lactic acidosis in patients with internal diseases. Am J Clin Pathol. 1983;80(4):484-9.

20. Kruse O, Grunnet N, Barfod C. Blood lactate as a predictor for in-hospital mortality in patients admitted acutely to hospital: a systematic review. Scand J Trauma Resusc Emerg Med. 2011;19:74.

21. Bakker J, Postelnicu R, Mukherjee V. Lactate: where are we now? Crit Care Clin. 2020;36(1):115-24.

22. Simon L, Gauvin F, Amre DK, Saint-Louis P, Lacroix J. Serum procalcitonin and C-reactive protein levels as markers of bacterial infection: a systematic review and meta-analysis. Clin Infect Dis. 2004;39(2):206-17.

23. Hamade B, Huang DT. Procalcitonin: where are we now? Crit Care Clin. 2020;36(1):23-40.

24. Gul S, Ozturk DB, Kisa U, Kacmaz B, Yesilyurt M. Procalcitonin levels and their predictive effect on mortality in Crimean-Congo hemorrhagic fever patients. Jpn J Infect Dis. 2015;68(6):511-3. 